\title{
Effects of Dietary Fat on Uptake Rate of Palmitic Acid and Lipoprotein Lipase Activity in Growing Chicks
}

\author{
Kazuaki TaKahashi, Yukio AKIBA and Tatsuro Matsumoto \\ Faculty of Agriculture, Tohoku University, Sendai-shi 980
}

(Received December 1, 1980)

\begin{abstract}
Three experiments were undertaken to investigate effects of dietary fat on the in vitro uptake rate of ${ }^{14} \mathrm{C}$-palmitic acid into the lipid soluble fraction of the liver and the adipose tissue, and on lipoprotein lipase activity in growing chicks. Three kinds of diet, a low fat diet (containing soybean oil $5.5 \%$ of total ME intake), a lard diet (containing soybean oil and lard, $5.5 \%$ and $27.3 \%$ of total ME intake, respecitvely) and a coconut oil diet (containing soybean oil and coconut oil, 5.5\% and 27.3\% of total ME intake, respectively), were used in these experiments. The chicks were given one of these diets to be isocaloric and isonitrogenous for 14 days. Lipoprotein lipase activity in the adipose tissue was not changed by the amount and the type of dietary fat. The in vitro uptake rate of palmitic acid into the liver and the adipose tissue was not affected by feeding the low fat, the lard or the coconut oil diet. This rate, however, increased with the rise of palmitic acid concentration in the medium. These results suggested that the in vitro uptake of fatty acids into the lipid soluble fraction of liver and adipose tissue was influenced by the substrate concentration rather than the amount and the type of dietary fat.

Jpn. J. Zootech. Sci., 52 (6): $472-477,1981$
\end{abstract}

It is well known that a high fat diet increases the rate of metabolizable energy utilization and promotes fat deposition in poultry ${ }^{1-3)}$. Our previous paper ${ }^{4}$ suggested that the chicks fed a lard diet gained more fat than those fed a glucose or coconut oil diet. We also observed that the in vitro rate of fatty acid synthesis in the liver, the adipose tissue and the muscle was not changed by feeding a glucose, lard or coconut oil diet ${ }^{5}$. Therefore, it will be considered that the increase in fat deposition by feeding a lard diet derived from the increase in the incorporation rate of dietary fatty acids into body fat.

The present study was undertaken to investigate effects of dietary lard or coconut oil on the incorporation of dietary fatty acids into the lipid soluble fraction of the liver and the adipose tissue in growing chicks. The incorporation rate of dietary fatty acids into these tissues was measured by the uptake rate of ${ }^{14} \mathrm{C}$-palmitic acid into the lipid soluble fraction of the liver and the adipose tissue, and by lipoprotein lipase activity in the adipose tissue.

\section{Methods}

Experiment 1. Four-week-old White Leghorn male chicks were used in the experiment. They were reared in the cage with wire floor, located in a laboratory 
room under automatically controlled temperature $\left(25^{\circ} \mathrm{C}\right)$. They were divided into 3 groups of 4 chicks each and given a low fat (5.5\% soybean oil of total ME intake), lard $(5.5 \%$ soybean oil and $27.3 \%$ lard of total ME intake) or cocount oil $(5.5 \%$ soybean oil and $27.3 \%$ coconut oil of total ME intake) diet for 14 days as described in the previous paper ${ }^{4}$. The experimental diets were used in the same compositions as described in our previous paper ${ }^{5)}$. At the end of the experiment, the chicks were killed by heart puncture. The liver and the abdominal fat tissues were removed and were placed in a ice-cold saline solution. The preparation procedures of the tissues were described in our previous paper ${ }^{5}$. A hundred $\mathrm{mg}$ of the tissue was incubated at $37^{\circ} \mathrm{C}$ for 2 hours in $3 \mathrm{ml}$ of Krebs-Ringer bicarbonate buffer. The buffer contained $10 \mathrm{mM}$ glucose, 1 or $2 \mathrm{mM}$ palmitic acid and $1 \mu \mathrm{Ci} 1^{-14} \mathrm{C}-$ palmitic acid. Palmitic acid was used as palmitic acid-bovine serum albumin complex which prepared by the method of Hawkins and HEALD ${ }^{6}$. At the end of the incubation periods, the tissues were rinsed with the non-labeled palmitic acid-bovine serum albumin complex until radioactivity was not counted. Total lipid in the tissues was extracted according to the methods of Folch et al. ${ }^{7}$. Radioactivities in the lipid and $\mathrm{CO}_{2}$ trapped Hyamine were counted as described in the previous paper ${ }^{5}$.

Experiment. 2. Animals and feeding procedures were the same as described in Exp. 1. Lipoprotein lipase activity in the adipose tissue was measured as follows: enzyme solution prepared by the incubation of heparin and the adipose tissue $\left(37^{\circ} \mathrm{C}, \mathrm{pH}\right.$ 7.4) was incubated with an activated substrate, chick serum and emulsified triglyceride (Intralipid) $(1: 1)$, and $20 \%$ bovine serum albumin $\left(37^{\circ} \mathrm{C}, \mathrm{pH} 8.4\right)$ for one hour. Lipoprotein lipase activity was expressed as the amount of fatty acid released from the activated substrate.

Experiment. 3. This experiment was undertaken to investigate the relationship between the substrate concentration and the in vitro uptake rate of palmitic acid. Animals and feeding procedures were the same as described in Exp. 1, except that the low fat diet was the only experimental diet used. The preparation of the liver and the adipose tissue, incubation procedure and tissue analysis were also described in Exp. 1. The buffer contained 0.5, 1.0,2.0 and $4.0 \mathrm{mM}$ palmitic acid.

Results were analyzed statistically by the methods of SNEDECOR and COCHRAN ${ }^{8}$.

\section{Results}

Table 1 shows the uptake rate of palmitic acid into the lipid soluble fraction of the liver and the adipose tissue, and into $\mathrm{CO}_{2}$.

Under the condition of $1 \mathrm{mM}$ palmitic acid, $\mathrm{CO}_{2}$ production from palmitic acid after feeding the lard or the coconut oil diet was not significantly different in both the liver and the adipose tissue, but under the condition of $2 \mathrm{mM}$ palmitic acid, $\mathrm{CO}_{2}$ production from palmitic acid in the adipose tissue in the chicks fed the coconut oil diet was lower in comparison with that in the chicks fed the low fat diet. Under the condition of $1 \mathrm{mM}$ palmitic acid concentration, the in vitro uptake rate of palmitic acid into the lipid soluble fraction of the liver and the adipose tissue was not affected by 
Table 1. Effects of dietary fat on the rate of palmitic acid uptake and $\mathrm{CO}_{2}$ production from palmitic acid into lipid soluble fraction of liver and adipose tissue (Exp. 1)

\begin{tabular}{|c|c|c|c|c|c|}
\hline \multicolumn{3}{|c|}{$\begin{array}{l}\text { Palmitic acid } \\
\text { concentration }\end{array}$} & \multirow[t]{2}{*}{ Low fat diet } & \multirow[t]{2}{*}{ Lard diet } & \multirow[t]{2}{*}{ Coconut oil diet } \\
\hline \multicolumn{3}{|l|}{ Liver } & & & \\
\hline \multirow{2}{*}{\multicolumn{2}{|c|}{$\begin{array}{l}\text { Palmitic acid } \\
\text { uptake }\end{array}$}} & $1 \mathrm{mM}$ & $85.4 \pm 20.1^{\square 2)}$ & $81.7 \pm 10.1^{a}$ & $79.0 \pm 2.8^{a}$ \\
\hline & & $2 \mathrm{mM}$ & $152.8 \pm 40.9^{a}$ & $134.9 \pm 44.8^{\mathrm{a}}$ & $121.9 \pm 43.9^{\mathrm{a}}$ \\
\hline \multirow{2}{*}{$\begin{array}{l}\mathrm{CO}_{2} \\
\text { production }\end{array}$} & 1) & $1 \mathrm{mM}$ & $10.8 \pm 0.3^{\mathrm{n}}$ & $10.2 \pm 0.3^{2}$ & $8.1 \pm 0.6^{a}$ \\
\hline & & $2 \mathrm{mM}$ & $16.9 \pm 2.0^{a}$ & $19.9 \pm 4.4^{\mathrm{a}}$ & $22.1 \pm 2.6^{\mathrm{a}}$ \\
\hline \multicolumn{6}{|l|}{ Adipose tissue } \\
\hline \multirow{2}{*}{\multicolumn{2}{|c|}{$\begin{array}{l}\text { Palmitic acid }{ }^{1} \\
\text { uptake }\end{array}$}} & $1 \mathrm{mM}$ & $136.4 \pm 18.8^{a}$ & $144.1 \pm 7.2^{2}$ & $183.5 \pm 52.0^{2}$ \\
\hline & & $2 \mathrm{mM}$ & $300.8 \pm 89.3^{a}$ & $229.8 \pm 23.0^{\mathrm{ab}}$ & $167.6 \pm 16.7^{b}$ \\
\hline \multirow{2}{*}{$\begin{array}{l}\mathrm{CO}_{2} \\
\text { production }\end{array}$} & 1) & $1 \mathrm{mM}$ & $13.8 \pm 2.1^{2}$ & $16.4 \pm 0.4^{\mathrm{a}}$ & $15.5 \pm 1.8^{\mathrm{a}}$ \\
\hline & & $2 \mathrm{mM}$ & $30.9 \pm 14.2^{\mathrm{a}}$ & $61.8 \pm 3.7^{b}$ & $49.1 \pm 11.1^{a}$ \\
\hline
\end{tabular}

1) Expressed as $\mathrm{n}$ moles $/ 100 \mathrm{mg}$ tissue $/ 2 \mathrm{hrs}$. 2) Mean $\pm \mathrm{SE}$ for 4 chicks. Mean values within a row followed by different superscript letters differ significantly $(\mathrm{P}<0.05)$.

Table 2. Effects of dietary fat on lipoprotein lipase activity in adipose tissue (Exp. 2)

\begin{tabular}{lccc}
\hline & Low fat diet & Lard diet & $\begin{array}{c}\text { Coconut oil } \\
\text { diet }\end{array}$ \\
\hline $\begin{array}{l}\text { Lipoprotein } \\
\text { lipase activity } 11\end{array}$ & $5.76 \pm 0.54^{23}$ & $6.68 \pm 0.72$ & $6.13 \pm 0.62$ \\
\hline
\end{tabular}

1) Expressed as $\mu$ eq fatty acid released/mg protein/hr. 2) Mean \pm $\mathrm{SE}$ for 6 chicks.

the amount and the type of dietary fat. However, under the condition of $2 \mathrm{mM}$ palmitic acid concentration, this rate in the adipose tissue after feeding the coconut oil diet was reduced as compared with that after feeding the low fat diet.

Table 2 shows the lipoprotein lipase activity in the adipose tissue. Lipoprotein lipase activity per $\mathrm{mg}$ protein was not changed by the amount and the type of dietary fat.

Figure 1 shows the relationship between the uptake rate of palmitic acid into the lipid soluble fraction of the liver or the adipose tissue and plmitic acid concentration in the medium.

The in vitro uptake rate of palmitic acid into the lipid soluble fraction of the liver or the adipose tissue was increased with the rise of palmitic acid concentration in the medium.

\section{Discussion}

It is well known that fatty acids in the site of the deposition are provided by fatty acid synthesis from carbohydrate and lipoprotein, especially from very low density lipoprotein (VLDL $)^{9}$. It is also known that the liver is a main site of fatty acid syn- 


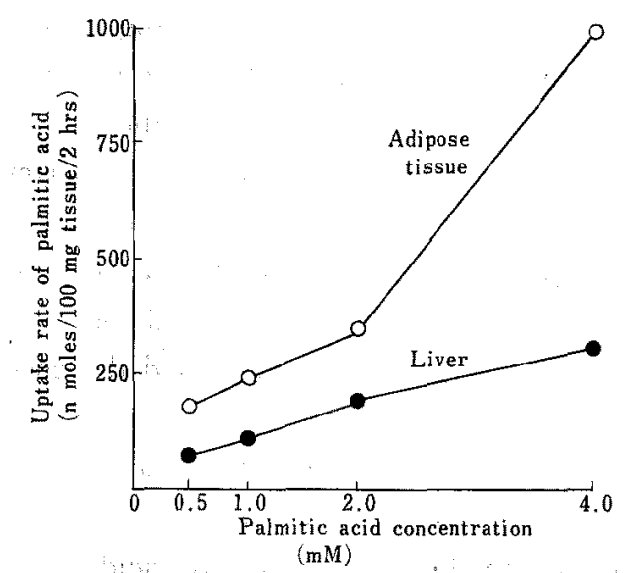

Fig. 1. Relationship between palmitic acid uptake and palnitic acid concentration in lipid soluble fraction of liver and adipose tissue. Each spot represents pools of 4 chicks.

thesis in the poultry ${ }^{10)}$ and VLDL formation in the $\mathrm{rat}^{9}$. On the other hand, hepatic fatty acid synthesis in the chicken was depressed by feeding a high fat diet ${ }^{10,11)}$. We estimated that about $50 \%$ of fat deposition by feeding a lard diet were achieved by the direct incorporation of dietary fatty acid into body fat ${ }^{12)}$. These results may indicate that the source of fatty acid in the site of fat deposition would be derived from VLDL when chicks were fed a high fat diet.

It has been reported that the uptake rate of palmitic acid in the rat liver increased with the increase in fatty acid concentration in the medium ${ }^{12}$. In the present study, the in vitro uptake rate of palmitic acid into the lipid soluble fraction of the liver increased with the increase in palmitic acid concentration, though this rate was not changed by the low fat or the lard or the coconut oil diet (Table 1 and Figure 1). WIEGAND et al. ${ }^{14)}$ reported that the activity of hepatic glycerophosphate acyltransferase in the rat fed a diet containing $2.5-15 \%$ safflower oil or cocoabutter diet was not changed. On the other hand, IRITANI and FUKUDA ${ }^{15)}$ reported that $\alpha$-glycerophosphate acyltransferase and diglyceride acyltransferase levels were reduced to $75 \%$ of that of controls fed $0.5 \%$ corn oil diet when rats were fed a diet containing $10 \%$ corn oil. Nicolosi et al. ${ }^{16)}$ observed that triglyceride secretion in the liver of gerbils fed a safflower oil diet was approximately twice as much as that of the coconut oil diet. Therefore, the results above mentioned and our results suggested that the fatty acid supply to compose VLDL was, at least, not changed by feeding dietary fat, though it was not known whether VLDL formation itself was changed or not.

Many researchers ${ }^{17-19)}$ reported that lipoprotein lipase activity in the adipose tissue of animals fed a high fat diet was not changed as compared with that of animals fed a low fat diet. In the present experiment, lipoprotein lipase activity in the adipose tissue was not affected by feeding the lard or the coconut oil diet (Table 2). Those results suggested that lipoprotein lipase activity did not change in response to dietary fat. 
We reported that carcass fat deposition by feeding a coconut oil diet was not increased as compared with that by feeding a lard diet $^{4}$ ). Our previous paper suggested that a cause of above observation was due to the increase in lipolytic activity in the chicks fed the coconut oil diet. In the present experiment, when the chicks were fed a diet containing coconut oil, the in vitro rate of palmitic acid in the lipid soluble fraction of the adipose tissue was not changed due to the rise of palmitic acid concentration in the medium. Therefore, this lack of response to the substrate concentration in the adipose tissue of the chicks fed the coconut oil diet might be also a cause of our earlier observation ${ }^{4}$.

We suggested that the increase in carcase fat deposition by feeding a lard diet was due to the increase in the amount of dietary fatty acids directly incorporated into body fat ${ }^{4,12)}$. If the increase in the amount of fatty acids directly incorporated into body fat is due to the tissue adaptation to the lard feeding, the in vitro uptake rate of palmitic acid into the lipid soluble fraction in the liver or the adipose tissue, and/or the lipoprotein lipase activity must be increased by feeding a lard diet. However, in the present experiment, the in vitro uptake rate of palmitic acid into the lipid soluble fraction of the adipose tissue was not changed by the amount and the type of dietary fat, though this rate markedly increased with the rise of palmitic acid concentration in the medium. These results suggested that the uptake rate of dietary fatty acids into lipid soluble fraction of the tissue was affected by substrate concentration and/or VLDL turnover rate rather than the tissue adaptation after feeding the dietary fat.

\section{References}

1) Carew, L. B. Jr., and F. W. Hill, J. Nutr., 83: 300-306. 1964.

2) De Groote, G., N. Rynthens and J. Amich-Galli, Poultry Sci., 50: 808-819. 1971.

3) Fuller, H. L. and M. Rendon, Poultry Sci., 56: 549-577. 1977.

4) Takahashi, K., Y. Akiba and T. Matsumoto, Jpn. J. Zootech. Sci., 50: 727-734. 1979.

5) Takahashr, K., Y. Akiba and T. Matsumoto, Jpn. J. Zootech. Sci., 52: 212-218. 1981.

6) Hawkins, R. A, and P. J. Heald, Biochim. Biophys, Acta, 116:41-45. 1966.

7) Folch, J., M. Lees and G. H. Sloane-Stanley, J. Biol. Chem., 226: 497-509. 1957.

8) Snedecor, G. W. and W.G. Cochran, Statistical Methods. 6th ed. The Iowa State University. Ames Iowa. 1967.

9) VAN Golde, L. M. G. and S. G. VAN DEN Bergh, in Lipid Metabolism of Mammals. (F. SNYDER ed.), 35-116. New York and London. Plenum Press. 1975.

10) Levellé, G. A., D. R. Romsos, Y-Y. Yeh and K. O’HeA, Poultry Sci,, 54. 1075-1093. 1975.

11) Romsos, D. R. and G. A. Leveille, in Modification of Lipid Metabolism (P. G. Parkins and L. A. Witting, eds), 127-147. Academic Press. 1975.

12) Takahashi, K., Y. Акiba and T. Matsumoto, Jpn. J. Zootech. Sci., 51: 197-203. 1980.

13) Kohout, M., B. Kohoutova and M. Heimberg, J. Biol. Chem., 246: 5067-5074. 1971.

14) Wiegand, R. D., G. A. Rao and R. Reiser, J. Nutr., 103: 1414-1424. 1973.

15) Iritani, N. and E. Fukuda, J. Nutr., 110: 1138-1143. 1980.

16) Nicolosi, R. J., M. G. Herrera, M. E. L. Lozy and K. C. HaYes, J. Nutr., 106; 1285-1297. 1976.

17) Pokrajac, N. and W. J. Lossow, Biochim. Biopys. Acta, 137: 291-295. 1967.

18) Delorme, C. L. M. and K. L. Harris, J. Nutr., 105: 447-451. 1975.

19) Borron, D.C., L. S. Jensen, M. C. McCartney and W. M. Britton, Poultry Sci., 58: 659-662. 1979. 


\section{Dietary Fat and Fatty Acid Uptake}

\section{鶏ヒナのパルミチン酸取り込み能とリポ蛋白質 \\ リパーゼ活性に扣よぼす給与脂肪の影響}

\section{高橋和炤・秋葉征夫・松本達郎}

東北大学農学部, 仙台市 980

鵎ヒナの食慨性脂肪の組織への取り达み能を調ベる目 的で, 肝臓上脂肪組織における ${ }^{14} \mathrm{C}$ ーパルミチン酸取り込 み能と脂肪組織におけるりポ蛋白質りパーゼ活性に対す る低脂肪飼料 (振取 ME の5.5\%の大豆油を含兄)，～ 一ド飼料（㳬取 ME の 5.5\%の大至油と $27.3 \%$ ドを含む)，ヤシ油飼料（摄取 ME の $5.5 \%$ 大豆油と

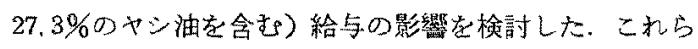
3 種の飼料を 4 週龄の白色レダホン種雄ビナに, 掫取代 謝土ホルギー量と掑取蛋白量が同一となるように2 週間 給与した、脂肪組織に㧍けるリポ蛋白賀リパーゼ活性は 給与脂肪の量と種類により影響されなかった。パルミチ
ン酸の肝蔵和よび脂肪組織への取り込为能も給与脂肪の 量と理類により大きくは変化しなかった。しかし，培善 液中のパルミチン酸浱度の増加に伴い，肝臓および脂肪 組織におけるパルミチン酸の脂質可溶性画分への取り迅 夕能は著しく增加した。これらの結果は, 食䬧性脂肪中 の脂肪酸の肝䁾および脂肪組織の脂質可溶性画分への取 り込多が, 給与脂肪の量や檑類によって, 組織の能力が 変化するためではなく，就し組織への基質流入量が速 度の変化によって変動することを示唆している。

日离会報，52(6)：472-477，1981 